Chapman University

Chapman University Digital Commons

English (MA) Theses

Dissertations and Theses

Spring 5-2021

\title{
Realism \& Language: How Luis Alberto Urrea Uses Bilingualism to Elevate His Works of Realism
}

Ashley Gomez

Chapman University, asgomez@chapman.edu

Follow this and additional works at: https://digitalcommons.chapman.edu/english_theses

Part of the Literature in English, North America Commons

\section{Recommended Citation}

Gomez, Ashley M. Realism \& Language: How Luis Alberto Urrea Uses Bilingualism to Elevate His Works of Realism. 2021. Chapman University, MA Thesis. Chapman University Digital Commons, https://doi.org/ $10.36837 /$ chapman.000275

This Thesis is brought to you for free and open access by the Dissertations and Theses at Chapman University Digital Commons. It has been accepted for inclusion in English (MA) Theses by an authorized administrator of Chapman University Digital Commons. For more information, please contact laughtin@chapman.edu. 
Realism \& Language: How Luis Alberto Urrea Uses Bilingualism to Elevate his works of Realism

A Thesis by

Ashley M. Gomez

Chapman University

Orange, CA

Wilkinson College of Arts, Humanities, and Social Sciences

Submitted in partial fulfillment of the requirements for the degree of

Master of Arts in English

May 2021

Committee in charge:

Joanna Levin, Ph.D., Chair

Justine Van Meter, Ph.D.

Rei Magosaki, Ph.D. 
The thesis of Ashley M. Gomez is approved.

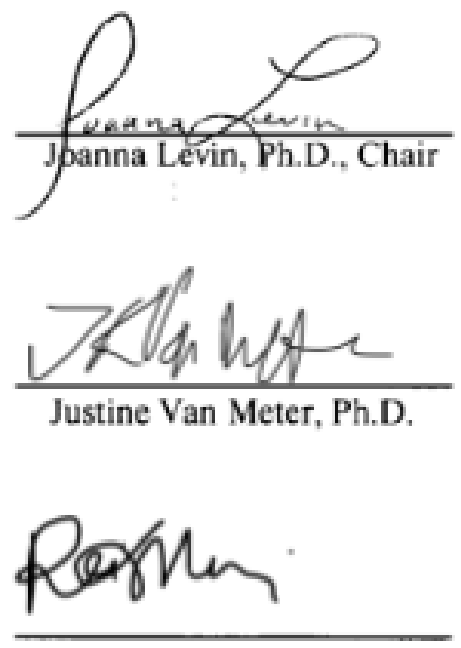

Rei Magosaki, Ph.D.

May 2021 


\title{
Realism \& Language: How Luis Alberto Urrea Uses
}

\section{Bilingualism to Elevate his works of Realism}

\author{
Copyright () 2021 \\ by Ashley M. Gomez
}




\section{ABSTRACT \\ Realism \& Language: How Luis Alberto Urrea Uses \\ Bilingualism to Elevate his works of Realism \\ by Ashley M. Gomez}

The trajectory of writer Luis Alberto Urrea stems from autobiography, poetry, fiction, and nonfiction, yet his works are not widely taught in academic settings, nor is there substantial scholarly work discussed on his published works. This thesis focuses on Urrea's trajectory in order to situate him as a realist writer, as I discuss Urrea alongside Amy Kaplan and Ramón J. Guerra. Alongside this I will also focus on his most unique aspect of realist writing that sets him apart from other realist writers, his use of English and Spanish within his works that forms itself into bilingualism. I will look into three examples of Urrea's published works: Across The Wire: Life and Times on the Mexican Border (1993) details Urrea's own experiences along the border as he educates readers on the lives, conditions, and language on the borderlands, The Tijuana Book of the Dead Poems (2015) depicts the blending of language within poetry alongside the experiences of Mexican-American immigrants, The House of Broken Angels (2019) describes a Mexican-American immigrant family's struggles as they both mourn and celebrate over several days who simultaneously show a blending of English and Spanish known only at a familial level. I argue that Luis Alberto Urrea's works require a deeper, academic discussion to allow for his realistic depictions to leave an impression on his readers, alongside placing Urrea within the realist tradition with his addition of language use. In looking at these works, a new aspect of realism has the ability to come forward within literature as we see Urrea use language in a progressive way. Across The Wire: Life and Times on the Mexican Border (1993) shows Urrea using Spanish to bring readers closer to the culture of those he describes. The Tijuana Book of the Dead Poems (2015) shows the coming together of the languages to depict experiences. The House of Broken Angels (2019) has a more colloquial take on language as Urrea uses it to show the intricacies of a domestic Mexican-American immigrants life. In placing these works in discussion together we can see how Urrea is depicting Latino/a realism. 


\section{TABLE OF CONTENTS}

Realism \& Language: How Luis Alberto Urrea Uses Bilingualism to Elevate his works of

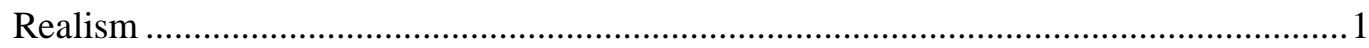

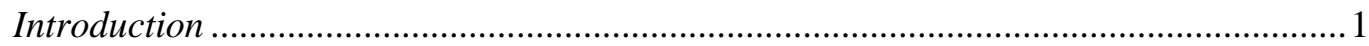

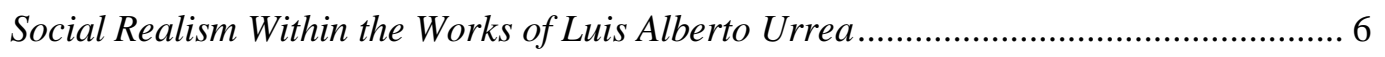

Across The Wire: Life and Times on The Mexican Border............................................ 15

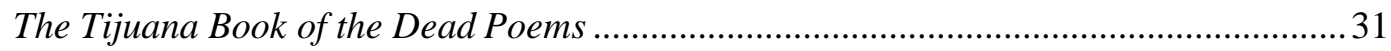

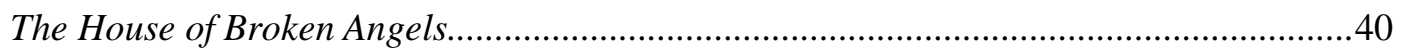

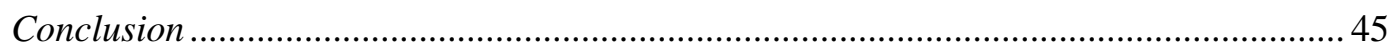

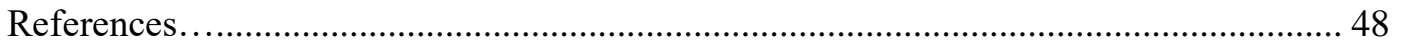




\section{Introduction}

The focus of my analysis will connect several important works of Luis Alberto Urrea.

Urrea is a Mexican-American author and poet born August $20^{\text {th }}, 1955$ in Tijuana, Mexico. He has produced a variety of novels, poetry, and essays that evoke undeniable Mexican and Mexican-American experiences. As an author, Urrea began his writing career with an autobiographical work and reportage titled Across The Wire: Life and Hard Times on the Mexican Border (1993), which details his experiences on and around the border with Missionary Pastor Von. Since then, he has published a large corpus of writing including a poetry collection The Tijuana Book of the Dead Poems (2015) that similarly discusses the borderlands in a lyrical and realistic manner within the text. Most recently, he has written a work of fiction that gives an inside look into a Mexican- American immigrant family in The House of Broken Angels (2019).

Within Across The Wire: Life and Hard Times on the Mexican Border (1993), I will be looking at how Urrea portrays the individuals he meets at the southern border in California, twenty miles from San Diego. Through these representations, he gives readers a glimpse of the rough, diverse, and bilingual culture of life on the border that allows him to put Spanish and English together for readers. In The Tijuana Book of The Dead Poems, my discussion will focus on Urrea's blending of language in order to convey a wide range of experiences in poetic form. Alongside this I will discuss what Urrea is choosing to share, and protect, through the poems he chooses to write in English and Spanish. My discussion of The House of Broken Angels will focus on the use of casual, familial English and Spanish within the MexicanAmerican immigrant household. I will also take a look at how, through his portrayal of this family, he is able to highlight a variety of realistic aspects through this highly authentic telling. 
These realistic aspects include Urrea's use of descriptive and sensory imagery, his portrayal of a variety of individuals, his use of emotion in order to trigger a response in his readers, and his use of language. My discussion of Urrea's works will look at several critics whose theories and ideas about realist representation and use of bilingualism, which I will be applying to these works. When analyzing Urrea's use of language, and specifically his use of bilingualism, I will be discussing Evelyn Ch'ien's work, Weird English (2005), as well as Doris Sommers' work Bilingual Aesthetics (2004). When discussing Urrea's place within the social realist tradition I will be drawing from Amy Kaplan's classic work, The Social Construction of American Realism (1988). By discussing all these critical and theoretical works alongside Urrea's texts I look to show the importance of bilingualism within his works and how it functions as a key element of his literary realism.

With this trajectory, it is unknown as to why Urrea remains rather unacknowledged, and underappreciated, as a writer. Although he has been reviewed in major publications, his works are not regularly taught at the academic level, nor is their substantial scholarly criticism addressing the importance of what he is doing within his works. Reviewers of these texts discuss these particular works of Urrea and they typically tend to note his descriptive writings, alongside his vital reminders of the lives that are led on the Mexican-American border: "Descriptive writing here sometimes reveals more than it feels decent to know, but Urrea's recognition of intact humanity — along with his accounts of kindness and generosity — gives this nightmarish tour its redeeming affection and hope." Similarly, another reviewer notes that "in the midst of the most brutal sequences, we are informed and shaken, made to feel the pain

\footnotetext{
1 "Book Review: Across the Wire Life and Hard Times on the Mexican Border" Review of Across the Wire: Life and Hard Times on the Mexican Border, by Luis Alberto Urrea. Kirkus Review, 1 January 1993.
} 
of others as if it were our own."2 These reviewers are gracious to Urrea and his work, but they do tend to glance over Urrea's unique use of bilingualism that I intend to showcase. Urrea's undeniably prolific writing will be the central focus of my thesis as I give merit to his ability to move across genres, his realistic modes of writing, and his modulation and control between the languages he uses. As aforementioned Urrea has written in multiple genres including autobiography, poetry, and fiction, and throughout the works Urrea advances a realist agenda.

Some of the scholars of the American social realist tradition, like Amy Kaplan, have discussed how realist authors portray a number of individuals and experiences. The social realist has long be associated with the city or urban setting, however within Urrea's novels he takes readers outside of the city, and gives an inside look into domesticity and private affairs within individual experiences. Alongside Kaplan we also see scholars such as Rámon Guerra who discusses Latino/a realism going into the 1920s within his essay "The Politics of US Latino Literature and American Realism." In doing this, Urrea exposes readers to the raw and gritty experiences of the individual throughout his works. These texts also contain the addition of language modulation. Urrea's unique ability to modulate his use of language and bilingualism as a mode of realism allows him to utilize it to showcase more than one perspective within a given text. One of the key concepts that Evelyn Nien-Ming Ch'ien notes within her texts is that of "weird English," which is described as "barely intelligible and sometimes unrecognizable English created through the blending of one more languages with English" (3-4). It is important to note that the weird English that Ch'ien describes differs from bilingualism; werid English blends language in doing so

\footnotetext{
${ }^{2}$ Unger, David. "Hell Is Near to San Diego." Review of Across the Wire: Life and Hard Times on the Mexican Border, by Luis Alberto Urrea. New York Times, 21 February 1993.
} 
werid English remains unique due to the specific blending we see by the user. In this case, our user is Urrea and his creation of weird English by blending and further bringing English and Spanish together. We see Urrea's use of language within Across The Wire: Life and Hard Times on the Mexican Border (1993) as the beginnings of how we will further see him use language within his texts. As Ch'ien notes, "For weird-English writers, the composition of weird English is an active way of takin' the community back" (Ch'ien 6). Urrea does just this, by telling readers of these narratives about selected individuals, and the community they make, he allows for the true culture and people to shine through. Similarly, these perspectives allow for Urrea to weave language and culture to create authentic voices in his works.

The United States has been a country that has seen a rise in population within the Latino/Hispanic community, approximately 60.6 million people in the U.S. identify as Latino or Hispanic and make up roughly $18 \%$ of the overall population within the U.S. ${ }^{3}$ More specifically looking at California the population is approximately 39.5 million people, and roughly 15 million people or $39.4 \%$ of the overall population identify as Latino or Hispanic ${ }^{4}$ Considering the size of the Latino and Hispanic population within the United States and California, we can see Urrea cater to and care about those he portrays. The size of the Latino and Hispanic population is relevant to Urrea because the need for telling the stories only increases as the population does. An accurate depiction of these people and

\footnotetext{
${ }^{3}$ Noe-Bustamante, Luis, et al. "U.S. Hispanic Population Surpassed 60 Million in 2019, but Growth Has Slowed." Pew Research Center, Pew Research Center, 10 July 2020, www.pewresearch.org/fact-tank/2020/07/07/u-shispanic-population-surpassed-60-million-in-2019-but-growth-hasslowed/\#: :text=Between\%202010\%20and\%202019\%2C\%20the,\%2C\%20behind\%20white\%20non\%2DHispanics.

4 “California Population 2021." California Population 2021 (Demographics, Maps, Graphs), worldpopulationreview.com/states/california-population.
} 
those who remain on the other side of the border is what Urrea is looking to tell, and by telling it gives the population another accurate portrayal of these people. I find this only bolsters his position as a significant American writer working in the realist mode.

Ultimately, Urrea is aware that the Latino/a and Hispanic communities are quickly growing in the U.S. This growth has given Urrea the opportunity to begin the discussion of their heritage, culture, and language, most notably through one of his characters, Little Angel. A reviewer notes that Urrea is describing individuals who are not that different from the readers themselves:

[Urrea] is more concerned with expressing Little Angel's belief, as he observes the intricacies of his family, that "if only the dominant culture could see these small moments, they would see their own human lives reflected in the other"5

As I look at how each of these texts has a place within the American Social Realist Tradition, I am looking to secure Urrea's works as more than what some would call "another book about starving Mexicans.” As Urrea was looking to get Across The Wire published, he encountered a New York publisher who refused to publish his work because they claimed "nobody wants to read another book about starving Mexicans." Soon after he gave up trying to publish the book, Anchor Books chose to publish the work.

It appears that since this phrase was first said to Urrea by the publisher that dismissed the importance of Urrea's border stories, a push has been seen to tell and share stories that those considered "voiceless" cannot. Allowing for works like Across The Wire: Life and Hard Times on the Mexican Border to continue to be published further allows the humanity of these

\footnotetext{
${ }^{5}$ Nguyen, Thanh Viet. “July’s Book Club Pick: A Novelist's Exuberant Love Letter to a Mexican-American Clan.” Review of The House of Broken Angels, by Luis Alberto Urrea. New York Times, 26 March 2018.
} 
individuals to be seen by more and more people. By continuously searching and searching for a publisher who would take his book, Urrea demonstrated his belief that more books depicting the realities of those living on the borders were needed. The end result are powerful accounts, of both fiction, and nonfiction depicting the Mexican-American people in perhaps some of the most raw, and real, ways we have available to us today.

\section{Realism Within the Works of Luis Alberto Urrea}

When looking at the number of texts Urrea has written it becomes clear that he writes realist works in order to share stories and tell the stories that would otherwise go unheard. Realism in itself has had a colorful background and history. In his essay "Transnational Precursors of American Realism" Bardeleben notes that "The beginning of American Realism and the end of romanticism are usually marked by the American Civil War" (Oxford 19). As we note that realism maintains a place within history, we can also see that through the years realism has evolved. Realism in itself is known to have a variety of outlets that allow for a wide range of authors to fit into this particular mode of literary writing. American Literary Realism has always been difficult to define; in light of this, I will look at the various definitions as they pertain to Urrea's texts. More specifically I will look at Urrea's text in relation to Amy Kaplan's work with social realism and Ramòn J. Guerra's article "The Politics of US Latino Literature and American Realism."

Amy Kaplan is an American scholar who worked within the field of American Studies while focusing on imperialism, culture, mourning, prison writing, and memory and war. Within The Social Construction of American Realism, Kaplan discusses the $19^{\text {th }}$ and $20^{\text {th }}$ century American societies that were continually in flux as this time period experienced monumental change within a short amount of time. Kaplan discusses the idea of realism's 
relation to social change and how literature depicting class difference, immigrant communities, and societies as they were further fueled the threat of social change. Kaplan discusses this idea of realism's relation to social change primarily through several authors and how their works "focus on class difference to forge the bonds of a public world that subsumes those differences" (12). Similarly, Kaplan takes on the topic of societal representation alongside the societal position of the author, as well as on the "...narrative process, on how realism works to construct a social world out of the raw materials of unreality, conflict, and change" (14).

Kaplan notes her main goal of this text "is ... to explore the dynamic relationship between changing fictional and social forms in realistic representation" (8). Kaplan looks to take a critical look at the literary realism and how it proceeds to influence the society around it. Kaplan argues, "For realists, the problem of representing social change is inseparable from the problem of representing social classes..." (10). I found this in particular to be an interesting conflict in representation that realists experience, and in this conflict it becomes even more difficult to depict the society as it is, or what the audience wants to hear. Realists' wanted to depict the society as it was, however when there was an accurate telling of a society, that same society found it as a threat. So, it then falls to authors to decide whether they depict society accurately or not in order for their works to not be seen as a threat. She also discusses that, "Realism is not to reflect passively a solid reality; it is to face the paradoxical imperative to use fiction to combat the fictionality of everyday life; unable to anchor itself in a stable referent, it must restore or construct a new sense of the real" (20). Here Kaplan is commenting on the idea that realism, in its fictional form, has the ability to construct a new reality for the society it is describing. 
There are also several instances where Kaplan discusses immigration in the late $19^{\text {th }}$ and early $20^{\text {th }}$ centuries; she notes

[I]n a society of immigrants in which many Americans did not speak the same dialect, let alone the same language, a common language had to be constructed against the counterforces of foreign tongues and social fragmentation. Realism may strive to make known to middle-class, 'cultivated' readers people, culture and ways of life that are foreign to them. (23)

By noting this disjointedness within American society, Kaplan also proposes a simple solution rooted in realism. Works that depict realism have the ability to depict lives, language, and cultures of others. Kaplan also includes the discussion of Jacob Riis' work How the Other Half Lives, an early example of photojournalism depicting the studies Riis conducted within the New York tenements and their unsightly living conditions. Kaplan notes that, "Riis crosses this line to enter the murky realms of lower-class life. Although his book aims to improve the living conditions of the poor, it appeals more immediately to the hearts and minds of his readers - the other 'other half' " (46). Kaplan also notes in regards to Jason Riis' work that, "Realism as we have seen, strives to pave a common ground for diverse social class by extending literary representation to the other half while reassuring middle-class readers that social difference can be effaced in the mirror of commonplace" (46). By noting that realism strives for common ground between social classes, Kaplan is also simultaneously discussing the real world implications it has.

Another consistency within Kaplan's work is her consideration of the setting of the various realist novels she discusses, most notably their use of the city and their urban setting: The city has long been viewed as both the setting and the subject of American realistic 
fiction at the turn of the century. In fact, we curiously treat the seamy side of urban life as the touchstone of 'the real' itself; thus the more slums, poverty, crime, corruption, the more realistic the novel. Late nineteenth century writing, however, suggests a more problematic relation between urban life and realistic representation. (44)

The city, according to Kaplan, becomes problematic as it has evolved to be considered closely with social change and in turn a threat to the society. These concerns do not stick with just the society that is being depicted within a text; rather Kaplan notes how the concern of social change and threats to society extends to the authors of realism.

Realism refers not only to the relation of the literary text to the world it represents, but also to the representation of the author to that world. If realism articulates anxiety about the accessibility of the social world to representation, it also expresses anxiety about the author's social position, which never occupies the complacent stance of the outside observer. (66)

Kaplan's discussion on culture I found to be of particular interest as she notes, "Realists do more than passively record the world outside; they actively create and criticize the meanings, representations, and ideologies of their own changing culture" (7). Although realists do record what goes on around them, Kaplan argues that while doing so they too have the ability take a critical look into their own culture. Further she also mentions that "Realism may strive to make known to middle class, cultivated readers people, culture and ways of life that are foreign to them" (23). The idea that realism has the ability to strive and share culture through its depiction of differing social classes and indviduals, according to Kaplan, also maintains what I intend to showcase Urrea is striving to achieve.

As Kaplan has described how realism functions in these different ways we can look 
more specifically into Latina/o Realism. Rámon J. Guerra's essay, “The Politics of US Latino Literature and American Realism" discusses the progression of Latino/a realism surrounding several historical periods in Latino/a history, including the 1848 Treaty of Guadalupe Hidalgo, Cuban Independence, as well as the Spanish-American War and the Mexican Revolution. One of the first things that Guerra notes is "Latino writers responded to an increasing awareness of their personal and communal reality and depicted this awareness in their choice of subjects and their methods of conveying their perspectives" (233-234). In noting this, Guerra is recognizing that Latino/a writers were aware of other writers depicting this community and culture, and in turn decided to write their own literature in order to more accurately depict the Latino/a community. Guerra similarly notes that

US Latino writers depicted historical, social and cultural events as a means to promote political change and drew upon the devices of realism-especially by grounding their writing in real, lived experience and moving toward a more accurate, and perhaps more critical, portrayal of their world. (234)

Guerra begins by discussing three authors that he found were prominent during the time of the 1848 Treaty of Guadalupe Hidalgo; these authors include Eusebio Chacon, Juan Nepomuceno Seguín, and María Amparo Ruiz de Burton. We see that "Chacon wrote melodramatic stories that celebrated Mexican resistance to neocolonialism and erasure by drawing attention to Mexican outlaws and others who resisted an oncoming Anglo domination" (235). Contrasting Chacon,

Seguín published his personal memoirs...[and] Seguín employed characteristics of the realist style, including portraying monumental events such as the battle of the Alamo mission in San Antonio through the eyes of families who were displaced 
because of the battle, thereby defining the epic through the familiar. (235)

Even further diving into the realist tradition we see María Amparo Ruiz de Burtons' work, which "...marks a transition [by] merging [with] a romantic plot with more realistic content and the incorporation of characteristics that align with the general definition of realism; namely in its recognition of the actual problems of life" (236).

As Guerra moves along we see him also discuss prominent writers that came out of Cuban Independence, and the Spanish-American War. These writers include Francisco Gonzalo "Pachin" Marin and Jose Martí. Latin American exiles, "Marín and Martí used the power of their written perspective to describe the lives of immigrants, revolutionary nationalism, cultural determination, and the experience of being perceived as second-class citizens" (238).

These writers, in their own way, "[t]hrough...poetry, essays, and journalism...created depictions of common experiences from the perspectives of Latinos/Latin Americans driven by a general but concerted effort to represent more accurately the whole of American experience..." (238). In this way we see these writers are focusing on their accurate depictions of the experiences of their people.

Within the final section of his essay Guerra brings to the discussion, Latino/a authors' responses after the Mexican revolution took place in 1910. The writers of this period included Mariano Azuela and Américo Paredes. Guerra notes that Mariano Azuela "wrote about the experiences of the common man during the revolution by invoking his own perspective as a doctor serving during the conflict" (242). Américo Paredes offered a different perspective with his "novel [that] invokes a much more authentic depiction of the immigrant experiences and the subsequent obstacles faced by those Mexican Americans and other Latinos who must 
navigate the evolving identity of living between two worlds" (243). Here, we can clearly see a progression of these authors subjects as they faced new challenges and social realities.

Ultimately we can see that Guerra contends that Latino realists and their works, focused on "experiences that were underrepresented and often dismissed by other, more mainstream writers...[whose accounts] were often incomplete when it came to representing racial and ethnic portraits of real, lived perspectives" (244-245). In lieu of these incomplete depictions we can turn to how Urrea is looking to fill the gap with his own works. With regards to Kaplan's and Guerra's works we can begin to fully situate Urrea as a realist writer.

As previously discussed Kaplan mentions this relationship between changing fictional and social forms of realistic representation, and we find that Urrea fits into this particular category by his use of multiple genres and various realistic portrayals and descriptions that respond to a changing social landscape. We see him write autobiography, memoir, poetry, and fiction, and within all of these he maintains realistic tendencies throughout. By realistic tendencies, I am referring to the way in which Urrea describes realist moments, through his use of descriptive and sensory imagery, his portrayal of a variety of individuals, his appeal to affect in order trigger a response in his readers, and his use of language.

In Across the Wire: Life and Hard Times on the Mexican Border, Urrea portrays various individuals along the Mexican-Border. Within these portrayals he is creating the world in which these individuals live in order to show them to the outside world and to demonstrate that they are deserving of attention. Urrea also notes the stark contrast within these families' social classes, which we are able to connect with as outside observers with the ability to compare to these families to our own and note the differences between the two. Throughout these specific texts Urrea showcases several different social classes: in Across the Wire: Life 
and Hard Times on the Mexican Border he shows the gritty barrios, "dompes," and those who are proud to live in them; in Tijuana Book of the Dead Poems he showcases a variety of individuals from both sides of the border and their social classes; and within The House of Broken Angels Urrea puts us into the center of an immigrant Mexican-American family living in San Diego. In doing this, Urrea shows how one can begin to connect different social classes to those who are not in that class, similar to Kaplan's idea that realism has the ability to strive to connect people through culture. Urrea is purposefully slowing the readers down to take time with those he portrays; in doing so he is able to reflect the ever changing reality of the borderlands. Within Across the Wire: Life and Hard Times on the Mexican Border, Urrea shows the everyday lives of the people who live on the border, by portraying these individuals, he constructs a new reality that readers have time to come to terms with. Further, we see that in Tijuana Book of the Dead Poems and The House of Broken Angels Urrea continues to construct new and unique realities. Urrea, similar to that of Riis in Kaplans' discussion, also describes a similar experience of the other half as his work Across the Wire: Life and Hard Times on the Mexican Border depicts the poor living conditions of the individuals he encounters, similar to that of Riis.. Ultimately, the end results of Urrea's various works aim to depict lives, the ability of languages to coexist, and to share borderland culture with those who would otherwise be unaware of these experiences. Although these are Urrea's goals, it remains important to share Urrea's own views: "I offer an introduction to the human value in these unknown lives, a story of hope in spite of horror and pain. What you read here happens day and night; the people you meet here live minutes away from you" (2). In this view he is trying to be as real and unsettling as he can in order for readers to maintain a grip on what he is about to tell them about. These specific texts of Urrea do not rely on the typical city, urban setting 
that Kaplan mentions. Instead, Urrea takes the reader outside of the city within his works. Across the Wire: Life and Hard Times on the Mexican Border takes place on the Mexican border city of Tijuana, and rather than describing city life, Urrea takes us into neighboring barrios and dompes away from the influence of city. Within Tijuana Book of the Dead Poems Urrea's settings are not stable, and move around dependent on the experience of individuals, and seemingly take place within smaller towns and along the border. Lastly, in The House of Broken Angels Urrea's Mexican-American family live their lives in the suburbs of San Diego. By moving his readers away from the typical urban, city setting of many realist novels, he has put the reader at the center of the Southwest American immigrant experience alongside those he portrays within his novels. When considering Urrea and his relation to the worlds he represents something that struck me was that Urrea was a part of these worlds he created and he wanted to do them justice within his writing. Through this text Urrea believes that "this book will put a face on the huddled masses who are invading our borders. I want you to know why they're coming" (4). Urrea articulates the various social issues that grip the MexicanAmerican immigrant and citizen communities, and he puts the readers at in the middle of all these issues and experiences rather than on the outside of the story. With Urrea and his writing he gives us an in-depth viewing of what goes on; readers are given information about the borders, and immigrant life and Urrea is our guide in navigating these difficult subjects.

As we move from Kaplan to Guerra, we can see how Guerra discusses and analyzes Latino/a writers and their topics of personal and community reality. In Guerra's discussion it is easy to be reminded of the realist topics that Urrea writes about, by grounding his works in real, lived experienced like he does within Across the Wire: Life and Hard Times on the Mexican Border. Similarly, we will note that Urrea also uses scenes of character drama and 
performance in The House of Broken Angels that further enhance its realistic tendencies. In comparing Urrea and Eusebio Chacon, we can see that within Across the Wire: Life and Hard Times on the Mexican Border Urrea also tells the stories of the individuals who are facing monumental events and struggles within their own lives who are also displaced in their journey towards the border.

Further, comparing Urrea and Ruiz de Burton, within The House of Broken Angels, Urrea portrays a Mexican-American family trying to handle the problems they face. These particular authors maintain a notion of realism throughout their texts, whether is it through resistance, memoir, or a more traditional realistic approach by depicting the problems of life. When looking at the writing of Marín and Martí, Urrea clearly does the same within the works I discuss by using his own unique perspective to describe the lives and experiences of immigrants.

Ultimately, we can see that like these Latino/a realist writers Urrea looks to invoke an authentic depiction of the immigrant experiences, and further shows a representation of Mexican Americans and Latinos who live between worlds. Urrea situates himself into the discussion as a Latino/a realist writer. Across the Wire: Life and Hard Times on the Mexican Border

Across the Wire: Life and Hard Times on the Mexican Border offers a look into life on the borderlands. An abundance of these stories that Urrea conveys take place a mere twenty miles away from San Diego, but they have an atmosphere and energy all their own. Urrea gives a candid look at the individuals and their journey in surviving along the border, while maintaining a hope for their future and their identity. This particular novel was taken from "about fifteen hundred pages of notes gathered on my travels with the missionaries from 1978- 
1982" (3) and then renewed in 1990. It is also important to note that on the copyright page of this text there is a disclaimer that notes, "The stories in this collection are true. Some names and identities, as well as specific locations, have been changed. In all cases, accuracy has been preserved in spite of consideration of security." I found this important to note in order for readers to fully find the stories that Urrea then tells as reliable. As this is the first text by Luis Alberto Urrea, it remains equally as important to note the magnitude of how he conveys the various hardships that those living along the border endure. Urrea details his various experiences in traveling to and from the Mexican border. One of the first things that Urrea notes, "Most of the people in these pieces urged me to tell their stories. They believed that if you knew where and how they lived, then they wouldn't simply fade away, relegated to as pointless a death as the lives they had been forced to live" (2-3). Although Urrea prefaces the text with various details on how the events that transpired did actually take place, the reader still faces the difficulty of truly having a connection with those that Urrea discusses. This connection may be difficult for readers to place themselves in the characters' shoes, because they may not be familiar with conditions that the various individuals find themselves in. However, Urrea places subtle descriptive details, "Pacha didn't have a television, but she did have an oil barrels: she cooked in one of them. The other she used to store water" (39). In this particular example, these brief details show the readers that Pacha does not have typical cookware, nor does she have an adequate way to store her water. These details are embedded into each story in hopes that the readers can have the opportunity to connect and empathize those in the text. Urrea's need to tell the stories of these people, and their experiences, simply comes off the page. As one reviewer writes,

Urrea leaves nothing to imagination in the pages of "Across the Wire" .. [H]e 
insists on writing with unflinching candor and raw clinical detail about the very worst manifestations of the disease, brutality, and sexual degradation that afflict the men, women, and children who live in the Borderlands. And if the reader is render sick at heart or sick to the stomach by the particulars of human misery, so be it. ${ }^{6}$

Ultimately, what Urrea presents in Across the Wire: Life and Hard Times on the Mexican Border is the raw, unfiltered, gut-wrenching stories of those who live on the borderlands.

In the first chapter entitled "Sifting Through The Trash," Urrea has complied a series of stories and has included subsections to separate each story he tells. Urrea centers this chapter around those whom he deems the "untouchables of this society." He notes that these "untouchables slept, among the pigs awaiting slaughter. I knew them all: the Serranos, the Cheese Lady, Pacha, Jesusita" (32). The Cheese Lady, also known as Doña Araceli, was a women Urrea and his team came to know as she greeted them every time they visited the dump with white goat cheese. She also became aware of new arrivals, and those who were in the most need of help from Urrea and his team. The Cheese Lady brought to Urrea's attention a new family that had arrived and they were in need of a home; the women's name was Jesusita. When we are introduced to Pacha, she and her family are in a similar situation as Jesusita, however Pacha ends up pregnant and is in need of medical care. The Serranos are a family that was brought to Urrea's attention, as the children were suffering horribly from scabies while the mother was pregnant and also very ill with what she claimed to be dysentery. The individuals noted above are just the beginning glimpses we get from Urrea of what is to come from his

\footnotetext{
${ }^{6}$ Kirsch, Jonathan. "The Brutal, Degrading Poverty of Tijuana's Borderlands." Review of Across the Wire: Life and Hard Times on the Mexican Border, by Luis Alberto Urrea. The Los Angeles Times, 10 February 1993.
} 
experiences.

When there is a depiction of true events, names of people and their descriptions are commonly changed in order to protect the privacy of that person who is being depicted. Urrea does not claim to change or even slightly adjust any of the identities of these people he discusses and calls them as what he knew them by. This attribute of Urrea's text I found to be crucial because it then became clear that those within this text had no need or want for Urrea to not tell their full and true story. With this in mind, this attribute alone has then allowed for Urrea to be seen as a vessel for these people and their stories. Similarly, Urrea does not hide away the more intimate and in some cases gruesome details of these experiences. One of the experiences he discusses within this chapter is that of Jesusita and her family.

In reading the account of Jesusita and her family Urrea is told by The Cheese Lady that "[s]he had discovered a new family — a married couple, several children, including toddlers, and one daughter with an infant — and they had no house to stay in. They were very poor, she said, and in dire need of help" (33). On his trips, Urrea frequently helped build homes for the poor; as Urrea puts it, "Requests for help were a constant; they were the rule. That Jesusita needed assistance didn't make her special, but something about her involved me right away. I suppose it is the thing we conveniently call 'chemistry.' Still, Jesusita was one face in a river of hundreds" (35). This description reveals a pull toward to Jesusita, but similarly reminds the reader that she is simply one of many. Urrea then meets Jesusita and her family and tells them that he will help them; however in a tragic turn of events, Jesusita and her husband are killed just as the house is nearly finished:

From the condition and location of the corpses, police pieced together this scenario...Jesusita's husband was held by the arms, and a sawed-off shotgun was 
notched under his nose and fired. It blew his head to pieces, leaving only the back of his skull, with the ears attached. This must have happened very quickly. Apparently the shooter had his shotgun under a coat. Jesusita and the boy ran. The child hid himself. The gunman went after her. She was not fast...They shot her in the spine, knocking her facedown in the dirt. They must have taken their time reloading, because she managed to crawl a short distance, bleeding heavily. The shooter walked up to her, put the shotgun to the back of her head, and fired. (55)

With their children nowhere to be found, Urrea is left to walk away from the work he did for Jesusita and her family, and onto the next family in need. By telling the readers what has happened to Jesusita and her husband he has unveiled the gritty details and unfortunate circumstances these individuals all too often face within their lives.

The second chapter entitled "Negra" relays the introduction of a little girl, Ana María (or Negra). Urrea writes,

Negra was a tiny barefoot girl who had curly black hair and large, startling white teeth. She was so skinny that she was firm as wood; when you picked her up, you could feel her angular pelvis and the chicken-wing bones in her back...Like most people in the dump, she was from elsewhere-freshly arrived from Michoacán— part of an immigrant drive north that died out at the border, either from exhaustion, fear, or a sudden draining of vision and will. (59)

These descriptions that Urrea presents us with a picture of Negra, a child who ended up just short of where she was supposed to be. Similar to Jesusita, Urrea was also taken with Negra and notes, "Whenever we'd pull in, I'd look for her...She would be with me for the rest of the day, helping me give out food to the women, whispering secrets in my ear..." (60). As Urrea 
continues to tell the story he makes note often of how Negra should be in school, but she was unable to attend school in Mexico without a uniform and shoes, both of which Negra did not have. Eventually Urrea takes Negra to buy shoes, "We bought Negra black shoes, and with some money to buy a uniform, she was able to attend school" (62). Although it appears that this situation will work out for Negra, Urrea presents the opposite:

One day, on her way back home from classes, a gang of barrio kids caught her, beat her up, and stole the shoes. She had to wait two week until she saw me again. I immediately bought her a new pair, but when she got back to the school they told her she failed and been expelled. She had missed too many classes. (62)

It appears that Urrea made a habit of seeing Negra and her family every two weeks, Urrea mentions, "it was a warm day in spring: we had pulled in with a huge load of clothing and food...I hadn't seen Negra for two weeks... Negra was gone" (62). Urrea ends this brief chapter with the last three words of the quote above. After this first mention of Negra, Urrea never stops looking for her every time he visits, and he frequently asks around to see if anyone had recently seen her. Urrea's search for Negra throughout the text is something that always struck me as unique; his search for her at times can even border on desperation and eventually stops for a period of time. However brief, this chapter present the readers with a question, "What happened to Negra?" and, unlike the other stories Urrea has presented with acceptable endings, the ending of Negra and her story leaves the reader stuck in their tracks; her ending is unfinished and immediately sticks out because of it. By leaving Negra's story unfinished so early in the text, Urrea appears to be showing the readers how life under these circumstances can change so quickly. 
Within the third chapter, entitled "Los Cementeros," Urrea describes his encounter with Andrés, a street kid who lived in a small house on a hilltop, who sleeps on the roof with other boys who were also street kids, "His name was Andrés. He awakened with the sun. He lay in bed as long as he felt like it" (65). Andrés lived in "what used to be a small house on a forgotten hill above downtown Tijuana" (65) as Urrea describes. The way in which Urrea meets Andrés is no special occasion:

On the night I first met Andrés, I was led up the alley by an ever fearless Von. All the other boys had heard us coming and vanished...Andrés stayed behind...He stayed behind because he had to-Andrés had two deformed knees that turned his feet perpetually sideways. He couldn't run. He couldn't even walk. He balanced on two aluminum crutches, and he moved slowly when he moved, his feet dragging and banging along the ground. (67)

These descriptions that Urrea presents of Andrés allow the readers to create a picture of him. By recreating Andrés on the page the readers are left to battle with the image of Andrés struggling to walk, while most of us live with the luxury of being able to walk unhindered. Later on in the chapter, Urrea describes the experience of getting tacos with Andrés and questions him about his legs:

“What's wrong with your knees?" I'd asked him. "I need surgery."

"Could you walk after it was done?" "That's what they say," he said. "How much does it cost?" He blew air out through slack lips. "Oh. Forget it. Too 
much." "How much?"

"Two hundred and fifty dollars," he said, shaking his head at the immensity of it. (6970)

Although Urrea does not mention Andrés past this chapter, Andrés' experiences alone have the ability to resonate with the reader, as well as their stark contrast. The readers will find themselves asking, "Would I be able to afford that surgery? Would someone pay two hundred and fifty dollars just so I can walk?” These questions leave the reader confused and emphasizes the luxuries the readers are presumed to have. By doing this, Urrea has given the reader the ability to begin to comprehend a small aspect of what those living on the border go through.

These stories presented above are a small portion of what Urrea has seen taken place along the border. These initial events take place from 1978-1982 and then Urrea steps away from life in Tijuana as work takes him to the East Coast. However, in 1990 Urrea steps back into the world he once knew in an incredible way by impacting the lives of those who read his stories, and by further impacting the children and the communities he visits. Within this text Urrea includes an epilogue entitled "Christmas Story," where he details how one of his published pieces was able to impact the neighborhoods in Tijuana that he once visited. Urrea was able to publish one of his border pieces in San Diego's alternative weekly titled the Reader. With this piece he was able to capture the attention of Cynthia Jeffery who worked in the advertising and marketing department for the radio station 91X; she wanted to do something for the people of Tijuana since the Christmas season was up and coming. Cynthia proceeds to set up a toy donation for the radio station's yearly Christmas drive with Urrea along for the duration of the event. For Urrea, this means returning back to a place where he had not been in almost ten years. As Urrea is now tasked to find a neighborhood where the 
donations will go, he observes significant changes:

The Tijuana colonia that had once established itself at Tijuana's garbage dump had changed since the days I'd written about. For example, it wasn't there anymore...The old dump site was now two warring colonias, Panamericano and Trincherazo. The active dump had moved several hills farther west. (166)

Despite these changes Urrea moves forward, and further asserts that he still feels a connection: Though the old dump had changed drastically, and though Negra had been missing from it for years, I still felt connected to the place. I still carried pictures of them all with me, showing them around my various English and writing classes. For all I knew, Negra was dead. On the other hand, she could have simply moved to a neighboring barrio and I'd never know where she was. She could have gone home to Michoacán; she could have crossed the wire; he could have died on I-5 running across at San Ysidro, or in Oceanside. There was absolutely no way to know. (168)

Urrea remembers this place and what it once meant to him; in this reflection we can also sense that there are some things that Urrea has left unfinished, the various families he visited that had happier endings than Jesusita, Negra and her family and where their journey had taken them even possibly across the border. the kids who were merely infants when he first met them. In his next trip to Tijuana to find a colonia to which the donations would go, he eventually settles on a compound and youth center that would be the recipients of the Christmas donations. As Urrea comes to this conclusion with other members of his group he briefly takes the reader out of the situation when he mentions, "But this is not the story I have come to tell you. Nor is the story of 91X's big broadcast, nor even what came after. Christmas 1990 began once all these events were finished. But we had to go through them to get there" (173). By taking the readers 
out of this original story Urrea is maintaining the notion that there are more important and impactful things to Urrea and therefore allows a more realistic personal view to come through. As Urrea and Cynthia begin this donation event Urrea is hopeful, and they eventually ended up with nine vanloads and then some: "It was coming far faster than we could load it...After the ninth load, more drivers had to come in — we were running double loads in tandem" (176). This type of success trickled into the next day of donations and once everything was loaded up and ready for travel, Urrea, along with Cynthia and several others, made the journey to the selected barrio; Urrea notes:

Then we were nearly there, and a group of women saw me and shouted, “iLuis! ¡Luis!” I said, "Somebody remembers me after all these years"... Three little girls charged into me, yelling, “¡Luisluisluis!” and kissing me. I didn’t know who they were. I looked up and Christmas came. Negra's mother, Doña María, was walking down the hill. And with her, a pretty young woman, very pregnant, and the young woman put out her fingers and touched me lightly and stared at me...I looked at María. "Yes," she said. “It's her." "I never forgot you, Luis” she said. "Did you ever forget me?” Negra. (183) As Urrea has been reunited with Negra he truly appears to found closure as he is able to aid in the rest of Negra's story. The idea that Urrea was able to have this type of closure seems almost implausible, but yet readers have had the ability to come full circle with a semblance of closure within Urreas' journey.

The reasoning for Urrea writing this is then not for his own gain, but rather allowing his audience to see this world for what it truly is, even though what Urrea shows is not a positive outlook. Lee Schweninger, a Native American scholar who has familiarity with working alongside minorities notes that the mode of realism gives these writers "the means and 
opportunity to take such necessary and important representation into their own hands" (Schweninger 180). Urrea's representation throughout the text remains instilled in the quote above, and allows the text to remain rugged, raw, and authentic within its stories. Urrea ends the preface of this text with a profound statement which led me to the reason he wrote these stories, "I have come to believe that when something is this bad, we look the other way, or we hope it's better than it looks. I trust this book will put a face on the 'huddled masses' who are invading our borders. I want you to know why they're coming” (3-4). Urrea wants his reasoning for telling these stories to his audience to be clear, and by providing a look into this world that Urrea himself experienced, he has given a voice to those who would otherwise be left voiceless. Alongside this, Urrea is speaking about a specific group of people and does not want his audience to make generalizations, "Nor is this book a portrait of 'the Mexicans.' I hope no general inferences are made about the nation or the people. This book is as much an overview of Mexico as a tour of the South Bronx is representative of the entire United States" (2). Within his comparison Urrea wants his reader to be aware that this picture he is presenting is not the full one.

As his first published work, Urrea made the decision within Across The Wire: Life and Hard Times on the Mexican Border to mostly write in English alongside italicized Spanish words that include translations. I found that this work was meant to be accessible for the average English reader. Although this text is presented in an English friendly manner it is unknown if Urrea translated his experiences with these individuals from Spanish to English or if he presents it as he experienced it. Another aspect I noticed that Urrea's use of English and Spanish within this text differs than the language that is present within The Tijuana Book of The Dead Poems and The House of Broken Angels. Reviewers have noted that "If there's a fault in 
this book, it is Mr. Urrea's need to translate common Spanish terms almost to the point of silliness, as when he tells us that "Negra" means "black girl" or that "pollos" are chickens. But this is carping"" . However, I find that by doing this Urrea is allowing for several things to happen. He is allowing for English speakers to fully access this text, while simultaneously showing the nuances of the language, we can see an example of this in a conversation between Jesusita and Urrea followed by an explanation from Urrea.

Jesusita shook my hand and called me "Hermano"_ "Brother." This is not a common Mexican greeting; it is used among Protestants as a shorthand for "fellow Christian." A "real" Mexican would never resort to such Protestant language (though it is a habit for Mexicans to call each other "'mano," which is short for "brother" but actually takes the place of "pal" or "dude." Mexican linguistics are a delicate and confusing art: mano also means "hand"). (34)

We can see here Urrea provides a translation for the initial word, and then further explicates the variances that also take place within the Spanish language. By describing these variances he gives English speaking readers a glimpse into the world of the Spanish language, alongside experiences of the individuals that have created this language.

As previously mentioned by the reviewer, Urrea provides a translation even when it appears "silly" to do so. However, I do not think this is a "silly" or taxing thing for Urrea to do. By doing this he has made the text accessible to anyone who reads it by helping them begin to understand it, and this is important to the overall goal of his text, which is to share the stories of these individuals.

\footnotetext{
${ }^{7}$ Unger, David. "Hell Is Near to San Diego." Review of Across the Wire: Life and Hard Times on the Mexican Border, by Luis Alberto Urrea. New York Times, 21 February 1993.
} 
Urrea maintains this realistic tone by allowing his readers to know he will not be generalizing about these individuals as well as through the language he utilizes throughout the text, and includes a way to define said language: "Linguists call the new border-speak 'Spanglish,' but in Tijuana, Spanglish is mixed with slang and pochismos (the polyglot hip talk of Mexicans infected with gringoismo; the cholos in Mexico, or Chicanos on the American side)" (14). Although Urrea mentions this combination of languages he appears to keep them separate from each other for a vast majority of the novel. However, both of these languages remain vital to the stories he tells.

Not only does Urrea portray this version of Spanglish, but he embraces it. His portrayal of this version of Spanglish is highlighted throughout his narratives, and to ensure that the readers are aware of what he is portraying, he makes a point to italicize most, if not all, of the Spanish and Spanglish words within the texts and provides a translation for these words when he uses them the first time around. This blending of English and Spanish that Urrea has put within his writing sets him up to incorporate what Evelyn Ch'ien terms "weird English." Ch'ien' research takes a look at the vernacular in U.S. literature in English as well as other languages which culminates in her work Weird English. As described by Ch'ien, "weird English" is "barely intelligible and sometimes unrecognizable English created through the blending of one more languages with English" (3-4). Urrea's Spanish is not "barely intelligible or unrecognizable English," but it is created by the blending of one or more languages. These two languages fuse together, and Urrea portrays with purpose. Ch'ien brings up prevalent aspects of language within her text, one of them being the idea of the author composing this new language as an active force, "For weird-English writers, the composition of weird English is an active way of takin' the community back" (Ch'ien 6). By introducing these two 
languages together within this text, as well as using weird-English in his other texts, Urrea has allowed for the culture of these people to shine through, and truly showcases their sense of pride. As a result of this, we see Urrea utilize this blend of English and Spanish in order to accurately portray the various areas and contexts that influence those who live on the border and that shape their language. Urrea presents us with an example of this:

Each dompe has its own culture as the people living there (Dompe is border-speak, a word in neither Spanish nor English. It is an attempt to put a North American word or concept—“dump”—into a Mexican context. Thus, “junkyard” becomes yonke and "muffler" becomes mofle.) (31-32)

The influence then of the American side of the border is present, as Urrea shows, even within these seemingly distant places. Another aspect that Ch'ien mentions in regards to weirdEnglish and their writers is that,

For the weird-English writer who begins to know a new culture along with the old, the resulting language will be a conflicted language, a language that defies being counted, or expressed as the sum of two or more languages. Instead it is a hybrid that seeks to emulate the structure of speaker and monolanguage. It is a hybrid seeking a monogalmous relationship with the speaker. This phenomenon describes the writer who is caught between languages. (37)

Ch'ien's assertion is perhaps the case for other bilingual or multilingual authors, but not with Urrea. Urrea is not an author that is contending with conflicted languages, rather he has been able to seamlessly weave these two languages to coexist together, and in doing so has created a hybrid as Ch'ien describes within her text.

Urrea undoubtably has created a unique language experience for his readers to 
embrace, and within this particular text an aspect that I found to be consistent and interesting is Urrea's use of translation and italicizing all if not most of the Spanish words within the texts. By utilizing translation within Across the Wire: Life and Hard Times on the Mexican Border Urrea has allowed the text to be accessible to readers who do not speak Spanish. We see that whenever Urrea presents a new word to the reader in Spanish, he also supplies them with the English translation. Similarly, whenever a word in Spanish is presented within the text it is italicized, it appears then that Urrea is trying to set it apart from English.

As we have taken a look at Urrea and the language he has created within this particular work, we then look to Doris Sommer and her work in order to understand the more tangible aspects of bilingualism that Urrea has used in order to go beyond the text itself. One of the first things Sommer mentions is, "[m]ore than one language is a supplement, not a deficiency" (xi); by mentioning this early on within her text she is setting the stage for bilingualism and multilingualism. In terms of how this applies to Urrea and his writing, his use of language is integral to his texts, and it is possible that if he were not bilingual, his stories may not exist if he did not know the language, therefore the language supplements and enhances his texts. Similarly, Sommer mentions,

From this perspective, knowing more than one language is humbling, because two languages make each one precarious, and also because adding one to one leads to a mathematically sublime world of languages where two or three or more are never enough. (14)

By knowing more than one language and then putting them together on the same plane has allowed Urrea for these languages to compliment the other and enhance both languages simultaneously. However, Sommer is aware that there are many different 
components to bilingualism and its various double-standards and potential issues, she writes:

They want to learn English in order to maximize their prospects. But learning is a process, so saving money on multilingual programs looks irrational and inefficient to many immigrants and to their friends. Effective assimilation, they say, is a gradual transfer from one language/culture to another. (ixvii)

This leads me to contemplate whether or not Urrea considered the idea of assimilation within his works. For example, within Across the Wire: Life and Hard Times on the Mexican Border, there is less Spanish then English in the text and it does appear that some of the individuals he encounters do speak English. It is not clear whether Urrea is simply translating their words into English, as this is not indicated explicitly. However, as we will see within the later works discussed, Urrea does place characters within a town that they are not native to. Urrea writes these stories from Tijuana; yet not everyone he meets is from there:

The streets and barrios are swelled with nervous strangers from Sinaloa, Oaxaca, Chiapas, Yucután, Quintana Roo...Salvadorans fleeing death squads, Guatemalans fleeing the soaring poverty and crime of their homeland, Hondurans and Nicaraguans fleeing God knows what. Tijuana is like a dam, and it's beginning to groan before a tidal wave of human flesh.(59)

Sommer also makes several important distinctions in regards to language; she first notes that " $[\mathrm{t}]$ wo languages (often more than two) and loyalties can bind one to a home country and to hosts. This can seem intolerable to patriots on either side of the border, and on 
both sides of their own divided selves" (19). By mentioning that in most cases language can bind one to their respective home countries there is a potential conflict within the various individuals and how they are bound or not bound to their homes within Urrea texts. It appears that within the texts I have included of Urrea's, most, if not all, of his characters have had the ability to remain adaptable through their own individual circumstances. Sommer also notes that "The observation is that most people normally live in more than one language" (158), Urrea clearly portrays this throughout his works but does so most notably in Across the Wire: Life and Hard Times on the Mexican Border. Ultimately by being a channel for these individuals and their stories Urrea can portray to readers a look into life at the Mexican border. It is within this text that readers get a first-hand experience of how bilingual individuals have the unique ability to live in both English and Spanish.

\section{The Tijuana Book of the Dead Poems}

In this collection of poetry, Urrea chooses to utilize English and Spanish in several ways. This collection contains eighteen poems in English, four poems in Spanish, and nineteen poems with a combination of the two. By having this collection contain poems in English, Urrea allows for English only speakers to feel like they're included within the experiences Urrea tells. Similarly, within the poems that contain both English and Spanish it appears that most readers who speak English or Spanish will be able to read these poems. However, there are also the Spanish-only poems to consider. By giving poems in Spanish, Urrea has allowed his Spanish speaking readers exclusive access to these unique poems. As I will explain, translations are approximations at best. In terms of access versus non-access within this text, it appears that whether you speak English or Spanish fluently, Urrea has created a work that will be accessible for his readers regardless of background. Urrea highlights life along the border 
and various other locations through the Southwest and it appears that most of these poems are told by migrants who are experiencing a variety of hardships. This text offers a lyrical look into the world of the borderlands. Uniquely enough Urrea is able to bring these various voices to light. Urrea works through gritty situations while maintaining the redeeming qualities of culture, pride and resilience. By Urrea portraying these locations as well as the individuals who find themselves in-between these locations, his poetry lends itself to being included within the realist tradition. When discussing realism in poetry, Johnathan Barron notes that "Realism in poetry, as in fiction, depicts everyday people in regular situations. It emphasizes the plausible, avoids melodrama, and concentrates, in poetry, on speech and the everyday talk of its characters" (Barron 487). This elevation of colloquial language can be seen in the opening poem of the text entitled "You Who Seek Grace from a Distracted God," the narrator of this poem lists the various times that make up the exhausting routine to work, "forgotten by $5: 15 \ldots$ here's your chance to drag home $/ \$ 80$ a week... Shiver. 5:35./it's 5:45...You reach the bench by 6:00...7:00.” (3). The consistent naming of the time appears to be doing more than just keeping track of time; it also tracks the difficult material realities and sense of alienation that the narrator is experiencing. We see this through the change in time and the activity the individual is performing within the poem that also changes. By doing this, the narrator sets the notion that the life they live is always in constant movement and struggle. By noting that life is ever changing even in the midst of routine, Urrea is preparing us for the changes that lie ahead within the poems that he presents to the readers. One way Urrea does this is by presenting poems that are both in English and Spanish. An example of this we see within the poem entitled "Siege Communiqué," which roughly translates to "siege communications." The narrator states, "by the river, no/body loved you Sister-/so close to Texas/so far from/ 
Revolución" (26). This slight change allows for Urrea to present a situation grander than the page he presents it on, most notably through his word and language choice. By choosing to use "Revolución" versus "Revolution," Urrea changes the way in which the reader sees this word, seeing it as something possibly foreign and perhaps even bigger than the context than Urrea is using it. The word revolución carries more to it then simply meaning or referring to a revolution; by using this word Urrea hints at the Mexican culture and the pride they carry in regards to their heritage. Another reason for which Urrea potentially uses this word, "Revolución," is to describe the very real issues within Latin American countries that continually spark revolution. Another poem entitled "Codex Luna" we see depiction of the borderlands:

My moon pulled a different darkness across the sky.

My unknown sister tucked in the barbed embrace of The border fences saw a different face in the moon. Theirs was a Luna Tochtli, a Rabbit Moon-moon of running, fear, hiding.

My bed was soft. Their beds were stone. My moon was origami floating in a water cup, a Japanese artwork of ricepaper and pearls. A light to dream of girlfriends. Their moon peeled a panicked eye, goggled blind as they ran. Headlights froze them, twin moonbeams ran them down, tufts of their dreams tangled in thickets 
of border tumbleweeds. (17)

This excerpt shows readers a comparison Urrea is making between comfort, and harsh border reality. The narrator describes who they call their unknown sisters. The narrator acknowledges their connection with those making the journey across the border. By detailing what these unknown sisters bring to the border and what the border fights back with, readers can begin to take a look at the realities and dangers that take place on the journey across the border.

As we see Urrea's word and language choice here it is then built upon in a poem entitled "Sombra," this poem is written entirely in Spanish, without translation:

Mi cara

en la orilla

de tu

pelvis

Yo

hincado

a tus pies:

suplicante

alabando

A tu olor

de mar, manzana,

margarita 
un minute, nada mas

Tú

ahora

tan delgada en mi memoria

como estas telarañas

de tinta. (30)

By writing this poem in Spanish without a direct English translation, Urrea presents an issue for a handful of readers, but does not exclude all of them. In some cases, the reader who does not speak Spanish is unable to read this, but the reader who does speak Spanish has an exclusive look into what Urrea has presented. With an exclusive look Urrea has allowed for his Spanish speaking audience to take precedence over the majority. However, it stands to reason that within my analysis, I provide a rough translation in order to show what Urrea is doing by utilizing Spanish within this poem,

Mi cara/ My face

en la orilla/ on the shore (or

edge) de tu pelvis/ of your

pelvis

Yo/ I

hincado/ On my knees

a tus pies:/ looking at your feet

suplicante/ begging (or imploring)

alabando/ praising 


\begin{abstract}
A tu olor/ To your smell
de mar, manzana/ of sea, apple

margarita/ daisy

Un minute, nada más/ One minute, nothing more

Tú/ You

ahora/ today

tan delgada en mi memoria/ you are a thin memory

como estas telarañas/ like these

de tinta/ ink spiderwebs (or cobwebs) (30)
\end{abstract}

It is important for me to note that this translation is in no way the exact way Urrea wanted this poem to come across. Rather, it is a general translation in order for readers to get a sense of what Urrea is portraying within the poem. It appears that within this poem the narrator that Urrea has presented is both sharing and veiling various aspects of someone they once knew. Readers are to come to the conclusion that the narrator is assumed male, and the one they are describing is female. More specifically, he is describing the female, or Latina body. The relationship we can see between the narrator and the individual that is being addressed can also appear romantic in nature. Therefore we can also view this particular poem through a romantic lens as well. One of the first things that drew me to this poem is the descriptive and sensory images that Urrea includes within the poem. Through the descriptive images presented in the first stanza Urrea has set the poem up with two individuals who are close to each other. As we look at the second stanza, the narrator begins to take action towards the other presumed female individual, seemingly asking and thanking her for something that only she can provide. Within 
the sensory images, presented in the third stanza, of the sea, apples, and daisies, the reader is immersed in the presence of this individual and connected to these smells that the narrator is experiencing. The fourth stanza consists of one line, noting how the narrator's memory of this experience merely last a mere minute and nothing else. As readers make their way into the fifth and final stanza the narrator appears to be reflecting upon the memory of this other individual, initially ensnared as in a cobweb, begins to fade more and more until there is nothing left but cobwebs. Alongside the overall portrayal of the poem, as well as its descriptive and sensory images, it is equally important to note that this poem is just one example of how Urrea creates a linguistic border through this poem. Whether intentional or not, this linguistic border that Urrea has created shows several things. Urrea is aware that only a specific group of people can truly understand what he is conveying, and in this is where we see the veiling of this experience to occur. The Mexican culture has long be known to have a history within the catholic tradition. As a result, the Mexican-American culture has remained guarded in regards to the things that are discussed publicly versus privately. Within "Sombra," Urrea has shared and veiled particular aspects that similarly cater to this tradition.

As previously mentioned there are only four poems within this collection that are written in just Spanish, and the other various poems are written either fully in English or showcase Urrea's use of both English and Spanish. Two poems written fully in English that I found to be impactful includes the poems entitled "Definition" and "Tijuana Codex." Urrea writes "Defintion" as follows:

Illegal Alien, adj./n.

A term by which

An invading colonial force 
Vilifies

Indigenous cultures

By identifying them as

An invading colonial force. (114)

By writing this poem in English, Urrea has presented the reader with a dilemma. Urrea identifies the native people as indigenous, and further comments on the colonizers that do not recognize the culture; the colonizers are the true invading force, yet, ironically enough, they identify the indigenous cultures as the invaders. In this conflict, Urrea stirs the reader's mind to be reminded of how stories are told and by whom they are told. Similarly, Barron mentions, "Abstract moral appeals to character, virtue, and duty were now accompanied by themes of direct political and social reform" (493). Within the poem above we see Urrea appeal to these abstract morals by implicating the political and social issues between these two opposing forces within the poem. In the second poem, "Tijuana Codex," Urrea writes, "Tijuana to here_-/ What a long rough walking road_-/ A red road, my road" (149). Urrea recounts his own experience while simultaneously connecting himself with others who have also taken this road. Alongside the poems in English and Spanish, we also see poems that are in both English and Spanish. In these poems, the majority of the words remain in English, but Urrea maintains lines in Spanish that do not disrupt the poem. We can see examples of this within the poem entitled "Irrigation Canal Codex": "Y los muchachos cling/ To the cantina's jukebox heart, sing:/ Y la muerte, esa puta que nos chifla/ From the bus station balcony, from I-10"(43). Within these poems, Urrea is able to communicate to his readers the possibility of two cultures 
trying to come together by seamlessly weaving these languages and experiences together.

As previously mentioned Urrea's combination of English and Spanish is an integral part of his texts. Within reading each text I came to consider his audience, and how they could potentially respond to the use of both languages. This particular collection of poems allowed me to look at yet another perspective of his audience. We have seen that Urrea presents poems in both English and Spanish, and when there is Spanish presented within the text there is no translation, differing from the amount of translations he supplied within Across the Wire: Life and Hard Times on the Mexican Border. I contemplated the potential reasoning for Urrea not supplying translation, and came to the conclusion that perhaps Urrea is giving his Spanish speaking audience insight that his English speaking audience would not understand, therefore making his Spanish speaking audiences reading experience more exclusive to them. It would appear however, that this exclusiveness for Urrea's Spanish speaking audience is short-lived. Urrea's English speaking audience has the ability to simply translate the words on the page, so the solution to being included within the exclusive community is seemingly solved. However, the Spanish language does not quite work this way. There are indeed cases where Spanish perfectly translates into English, but most times this does not happen. There are a number of things to take into consideration when reading Spanish, like the various accent marks and extra punctuation that is needed. Alongside these examples we must also consider that this language is one that is meant to be spoken in order to fully understand its meaning. For example, the way certain words are said with the tiniest change in tone or inflection can give a completely different context and attitude toward what was just said. This can further lead the Spanish speaking audience to have different interpretations of a single word or poem because when written on the page readera are unable to tell how Urrea truly wanted a certain poem to be 
read.

The House of Broken Angels

The House of Broken Angels offers a story that centers on a Mexican-American family in the suburbs of San Diego. Urrea tells this story with regards to both sides of the border as well as spanning several generations. The novel focuses on patriarch, Miguel Angel de La Cruz (also referred to as Big Angel), and his entire family, as they spend two days mourning while also celebrating his birthday. The House of Broken Angels opens with Big Angel lying in bed startled to find his fathers' ghost sitting beside him on the bed. This brief interaction may appear fantastical, however the overall ordinary aspects of the novel lend this scene to be interpreted as a vision or a reflection. I find it to be considered in this way because Big Angel is aware he is dying and is likely projecting his grief into the form of his own father. Similarly, as Big Angel is aware he is dying and he is being reminded of those who he has lost, and is aware that he becoming closer to those who have previously passed like his father. As we continue to learn about Big Angel and his relationship with his father, this vision he has can also be seen in finding comfort in his inevitable fate. What Urrea has presented is nothing less than a work of authentic culture told through unbreakable familial bonds. Reviewers note that "This is hardly a fresh setup — the big ethnic gathering as plot engine is a fairly tired devicebut Urrea's embrace of it is so ardent, and his execution of it so energetic, that he blows right past any reservations about originality" . By embracing what he has placed in front of readers, Urrea proceeds to narrate the various events that take place surrounding these events through the eyes of various characters. This particular work of Urrea struck me as unique due to the

\footnotetext{
${ }^{8}$ Lindgren, Michael. "A family saga with bounding heart, poetic delivery and plenty of swagger." Review of The House of Broken Angels, by Luis Alberto Urrea. The Washington Post, 8 March 2018.
} 
variety of realistic qualities that Urrea has included throughout the text. One of the first things I noticed within this novel was the unique use of English and Spanish that only someone who has lived within a similar environment to the characters in the novel is able to recognize. This casual English-Spanish dialect takes the novel from a place of otherness to one that can hit near home, alongside this dialect Urrea simultaneously details the intricacies of MexicanAmerican families and homes. This type of dialect Urrea shows primarily appeals to readers who speak both Spanish and English fluently. Another aspect of his use of language that I noticed was that this blending of English and Spanish is perhaps the most accessible to nonSpanish speakers, therefore making this text accessible to the majority. Urrea tells this story from an omniscient point of view as the narrator goes from character to character to show the variety of people who make up this family. The narrator describes how Big Angel learned English when he immigrated to the US, he learned by memorizing the dictionary and learned new words by playing card games with others until his English words no longer had an accent on them. It is within the various transitions from character to character that allows Urrea to illustrate the familial connections between them. Urrea presents these familial connections through small scenes of intimacy that can easy be overlooked. One of the first examples we see of this is when Big Angel details how his mother describes rainbows:

When he was a boy, Mother had taught him that a rainbow was a bridge where angels walked down from heaven. In Spanish is was an arco iris. This was so much more lovely than English, like the name of a butterfly or hummingbird or daisy. He felt smug about this: go, Spanish! Sunflower: girasol he thought.

girasol

mariposa 
colibri

margarita. (27)

As Big Angel reflects on what his mother told him, it is shown that there is a lasting impression that his mother has made upon him with its loveliness, sealing their connection as mother and son. Alongside this connection we can also notice within this quote that Big Angel is thinking words in English, and then again in Spanish, as if comparing the two. With this comparison between the languages Big Angel appears to find the Spanish words more beautiful and appealing than the English words.

Another example of this we see in an exchange between Minerva (Minnie) and her mother Perla:

“Mija,” she called to dear Minnie. "Minerva! Café, sí? Por Favor, mi amor.” Minerva, thought La Minnie. Why did she have to have the weird name? "You got it, Ma!" she called. “Comin’ right up!” "Qué?” Perla had only lived in the United States for fortyone years - she couldn't be expected to learn English overnight. (95)

This particular scene may not strike the reader as an important one, but it has allowed Urrea to showcase several important features of the Mexican-American family. The tension-filled exchanges like the one we see above between Minnie and her mother, in which Minnie's mild frustrations are narrated but remains unvoiced except through her own refusal to reply to her mother in Spanish, are consistently seen within this family dynamic and are standard within this type of multi-generational immigrant household. Big Angel's wife, Perla, is a hardworking, first-generation immigrant and mother to Minnie and Lalo. She is also mother to El Yndio and Braulio, whose father is not Big Angel. Minnie is similarly hardworking like her parents, and she holds her family close to heart despite her guarded demeanor. This 
type of language used between Perla and Minnie, is the type of blending of languages that Urrea can be seen throughout the novel. This scene in particular contains Spanish, but not an overwhelming amount that would lose English only speaking readers. Urrea gives the readers just enough context of the action happening between these characters that they can begin to decipher what the Spanish words mean. By portraying these mixed-language scenes, Urrea has created another relational dynamic of the novel.

Alongside this unique language use, it is also through this simple act for her mother that Minnie has the ability to create this intimate moment with her mother and their blended language. Not only do we see these moments happen between mother and son, and mother and daughter, but we also see these moments happen between siblings. The mixed-language dialogue does not always represent alienation between the characters, as we saw with Minnie and her mother, but it can mean a connection made through language. In the following example we see an exchange between Little Angel and his half-brother César, also known as Carnal:

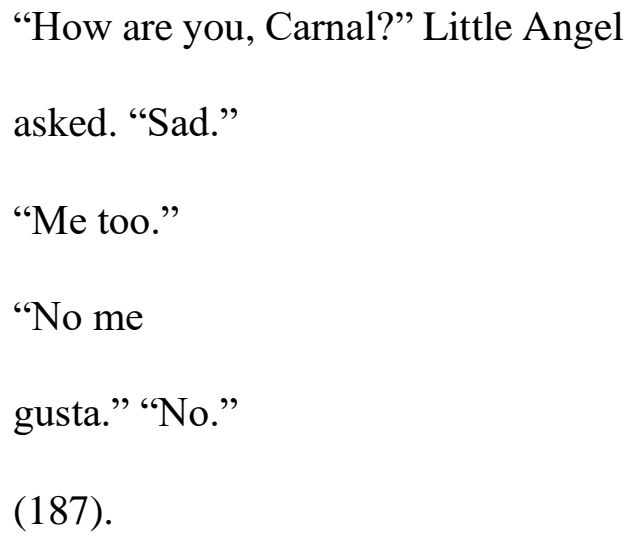

Within this brief exchange we see that these two characters are expressing the same level of grief in coming to the realization they do not have much time left with their older brother. As they express this grief, they also share in it, therefore creating an intimate moment between 
siblings. This particular scene brings the vulnerability of two brothers sharing in grief right to the reader, something that most readers can relate to. By giving readers this scene, Urrea has prompted a potential emotional response from the readers as they are thrust into this grief filled scene.

Alongside these individuals sharing these intimate moments we also see this occur between Big Angel and Minnie:

Big Angel was still wiping his eye when he kissed Minnie five times. At the end of the day, all he really knew was that he was a Mexican father. And Mexican fathers made speeches. He wanted to leave her with a blessing, with beautiful words to sum up a life, but there were no words sufficient to this day. But still, he tried. "All we do, mija," he said, "is love. Love is the answer. Nothing stops it. Not borders. Not death." He held her hand in his burning fingers, only pulling away when a shaken Perla wheeled him back to his bedroom. (235)

This is a particular moment that Big Angel and Minnie share; however everyone around them feels the effect. It is within these various instances where we see can Urrea bring these characters and their intimate experiences off the page. Both of these passages noted above have similar things in common, the language use as well as emotions that are carried within them. By placing both language and emotion together within this text Urrea has brought real emotions and therefore experiences within the realm of his writing.

Similarly, all of the passages noted thus far also contain characteristics of performance, and Urrea's characters do not disappoint in their performance. The characters are real in their drama, loyalty, confidence, emotion, and vulnerability, as a reviewer describes, "Everyone's a performer. It takes a certain courage to perform. A person on stage has to be vulnerable, ready 
to hear laughter when she didn't want it, or see an eye-roll when he's looking for tears. The vulnerability on display in this novel is what makes it exceptional"'. The characters are real in their drama, loyalty, confidence, emotion, and vulnerability and ultimately make the novel as memorable as Urrea intended it to be.

The bilingualism within this novel is perhaps the most drastically different than in the other two texts I have discussed. In Across the Wire: Life and Hard Times on the Mexican Border, Urrea portrays the blending of languages that happens along the border and comes to portray his unique version of Spanglish. In Tijuana Book of the Dead Poems, Urrea presents Spanish and English in several ways. He depicts Spanish by itself and weaved through English and similarly depicts English by itself. By contrast, in The House of Broken Angels, we see Spanish and English used within a familial setting. This familial setting gives a whole new look into the Spanish language to the non-Spanish speaker.

\section{Conclusion}

As I have discussed Urrea's placement within the American Social Realist Tradition alongside my analysis on Kaplan and Guerra's works, I have been able to draw several conclusions. Urrea brings forth a new discussion on Latino/a American Realism, that focuses on border life, that progresses to describing contemporary Mexican immigrant experiences in more realistic forms.

This progressive use of language that we see within Urrea's work is merely the beginning of a discussion that can further enhance the way one can view a language, or

\footnotetext{
${ }^{9}$ Meyer, Lily. "Despite A Sad Setup, 'House of Broken Angels' Hums With Joy.” Review of The House of Broken Angels, by Luis Alberto Urrea. NPR, 7 March 2018.
} 
multiple languages, within a text. Within Across the Wire: Life and Hard Times on the Mexican Border we see Urrea utilize language in order for his readers to understand the Spanish language and how it is portrayed along the border. Alongside his use of language, Urrea has allowed for the gritty details to break through this work and shows the lives of those who live on the other side of the border. The Tijuana Book of the Dead Poems utilizes language in a way that both conveys and protects the Mexican culture, while sharing the experiences and blended language of immigrants as they enter the U.S. In order to portray these experiences, Urrea uses descriptive and sensory images alongside his poetry. Within The House of Broken Angels we further see the use of Urrea's blended language through his portrayal of a Mexican-American family that has made a life after immigrating to San Diego. By capitalizing on showcasing the most domestic and private affairs of a family, Urrea has shifted the realistic look away from the city, to the individuals and their experiences often overlooked because of its remote location along the border while also creating a space for private experiences, family, and community. It is these works that allow for language and realism to work in tandem in order to produce unique works that allows for readers to get a glimpse of the experiences Mexican- American people go through. This telling of these experiences allows for a new space of discussion to occur and, with luck, have a potential to further influence how these individuals are seen by those on the other side.

More specifically with these three works, I conclude that readers are given a realistic look into the Latino/a American experience from various perspectives through Urrea's works. We see in Across the Wire: Life and Hard Times on the Mexican Border how Urrea tells the stories of those who are considered voiceless and how he was able to impact those he encounters. In The Tijuana Book of the Dead Poems, the blending of language through his 
poetry is apparent, and allows for English and Spanish speakers alike to take something away from these experiences. The House of Broken Angels also gives a look into what these immigrant experiences that have been told have the potential to be through this MexicanAmerican immigrant family. These experiences go to show us that Urrea's realistic writings on the Latino/a experience is the beginning of a discussion that needs to be had on his published works and on those who he portrays. 


\section{Works Cited}

“Across the Wire: Life and Hard Times on the Mexican Border." Luis Alberto Urrea, 19 Dec. 2017, luisurrea.com/books/across-the-wire-life-and-hard-times-on-the-mexicanborder/.

Bardeleben Von, Renate. "Transnational Precursors of American Realism”. The Oxford Handbook of American Literary Realism, edited by Keith Newlin, Oxford, 2019, pp.19-39

Barron, Jonathan. "Realism and Poetry". The Oxford Handbook of American Literary Realism, edited by Keith Newlin, Oxford, 2019, pp.487-505

Ch`ien, Evelyn Nien-Ming. Weird English. Harvard University Press, 2004.

Guerra J, Ramón. "The Politics of US Latino Literature and America”. The Oxford Handbook of American Literary Realism, edited by Keith Newlin, Oxford, 2019, pp.233-248

Kaplan, Amy. The Social Construction of American Realism. University of Chicago Press, 1992.

Newlin, Keith. The Oxford Handbook of American Literary Realism. Oxford University Press, 2019.

Schweninger, Lee. "Native American Realism". The Oxford Handbook of American Literary Realism, edited by Keith Newlin, Oxford, 2019, pp.165-183

Sommer, Doris. Bilingual Aesthetics: a New Sentimental Education. Duke University Press, 2004.

Urrea, Luis Alberto, and John Lueders-Booth. Across the Wire: Life and Hard Times on the Mexican Border. Anchor Books, a Division of Random House, Inc., 1993. 
Urrea, Luis Alberto. The House of Broken Angels: a Novel. Back Bay Books/Little Brown and Company, 2019.

Urrea, Luis Alberto. The Tijuana Book of the Dead: Poems. Soft Skull Press, an Imprint of Counterpoint, 2015. 